\title{
Geotechnical study to assess the weir stability on high erodible soils
}

\author{
Riaed Saee Jasim Al-Saedi ${ }^{1}$, Zahraa Rasul Fakher ${ }^{2}$ \\ ${ }^{1}$ Assit. Prof. Engineering Geology and Geotechnics, Civil. Dept., Engineering College, Misan University, Iraq. \\ ${ }^{2}$ Misan university/ Engineering College, Iraq.
}

\section{Article Info}

Received, 2019

\section{Keyword:}

SEEP/W,

Factor of Safety,

Uplift pressure,

Hydraulic failure,

Dwerige weir

\section{Corresponding Author:}

Riaed Saee Jasim Al-Saedi,

\begin{abstract}
Dwerige weir is a concrete hydraulic structure construct as flooding protect and water harvesting system for replenishment ground water in the area. The foundation comprised of highly erodible alluvial fan deposits. SEEP/W used to analysis foundation soil stability against piping erosion resulting from the water seeps. The two dimensions steady state model are selected, and saturated only materials used in the analysis. The results show that the soil need more actions to support the foundation during the weir economic life.
\end{abstract}

Assit. Prof. Engineering Geology and Geotechnics,

Civil. Dept. , Engineering College,

Misan University, Iraq.

Email: Dr.Ra.Iraq@uomisan.edu.iq,Rd.iraq@gmail.com

\section{Introduction}

The effects of water leakage beneath dams and other hydraulic structures are the main objectives of any project stability assessment. This leakage caused many serious problems in the structure foundation soils, like seepage erosion, soil heave, and uplift. The type and intensity of these problems depends on the hydraulic head and geotechnical properties of foundation soil like hydraulic conductivity and particle size [1,2]. To understand the behavior of any dam or weir foundations against piping, a numerical, analytical and experimental analysis methods are developed to simulate the water and soil failure during project life. Saleh, et al [3] used SEEP/W finite element package to analyse the seepage flow under Diyala weir foundation. They concluded that the weir foundation corrosion of the sheet piles especially in upstream causing increasing seepages below the dam. Finite element method used to estimate the quantity of seepage flux and to estimate the factor of safety of foundation against piping soil erosion [4]. The cutoff installed to reduce the seepage effect and uplift pressure below dam base [5].

\subsection{The problem of the Study}

The soil succession in Dwerige weir site comprised of granular soil (SM) cemented with cohesive materials (clay and gypsum) (Figure 2.a). This soil tends intensely to erode by water seeps on and through soil particles. and there are many roads and hydraulic structures fails as a result of piping erosion (Figure 2.b). And there are many examples of fa, this study aimed to:

a. Compute the uplift pressure and vertical gradient beneath weir foundation by SEEP/W model

b. Estimate the total seepage in the downstream of the weir.

c. Compute the factor of safety against vertical piping. 


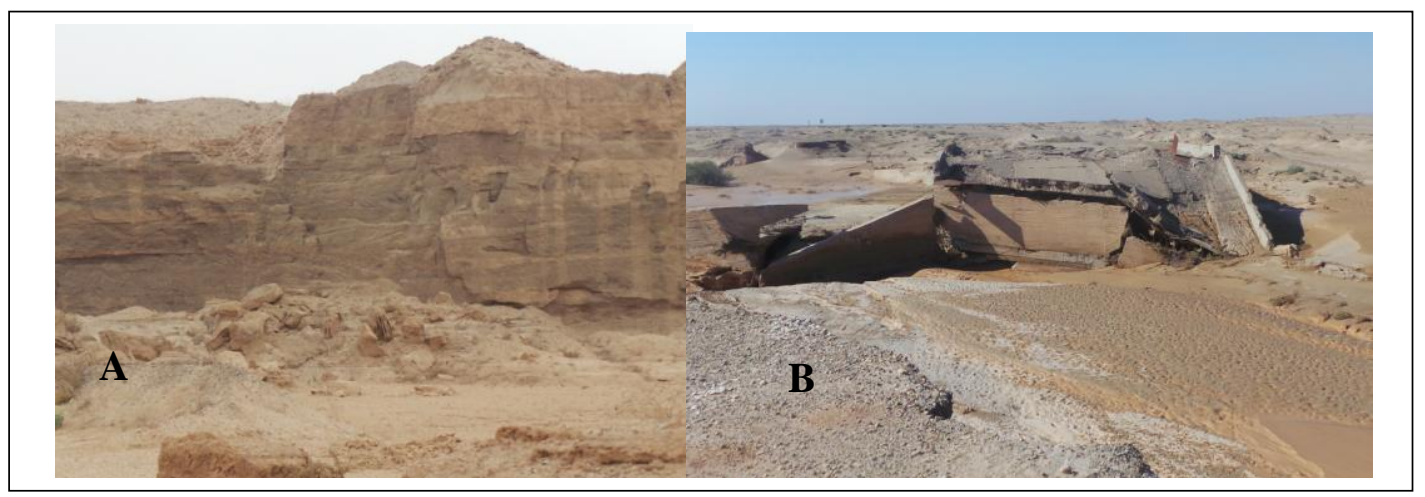

Figure 1. A. The weir foundation soil as outcropped in a quarry near weir site.

B. Seepage erosion effects on the hydraulic structures and roads, near Dwerige weir.

\subsection{Location of Dwerige weir}

Dewerige dam located in south eastern part of Maysan province, south of Iraq as shown in Fig.1.1. The coordinates of dam axes of dam are (E746239.862, N3551456.909) - (E746256, N3550931). The weir body is concrete structure of $512 \mathrm{~m}$ length and total storage capacity of $1870000 \mathrm{~m}$. The main purpose of the weir is flooding control and for water harvesting system in the area.

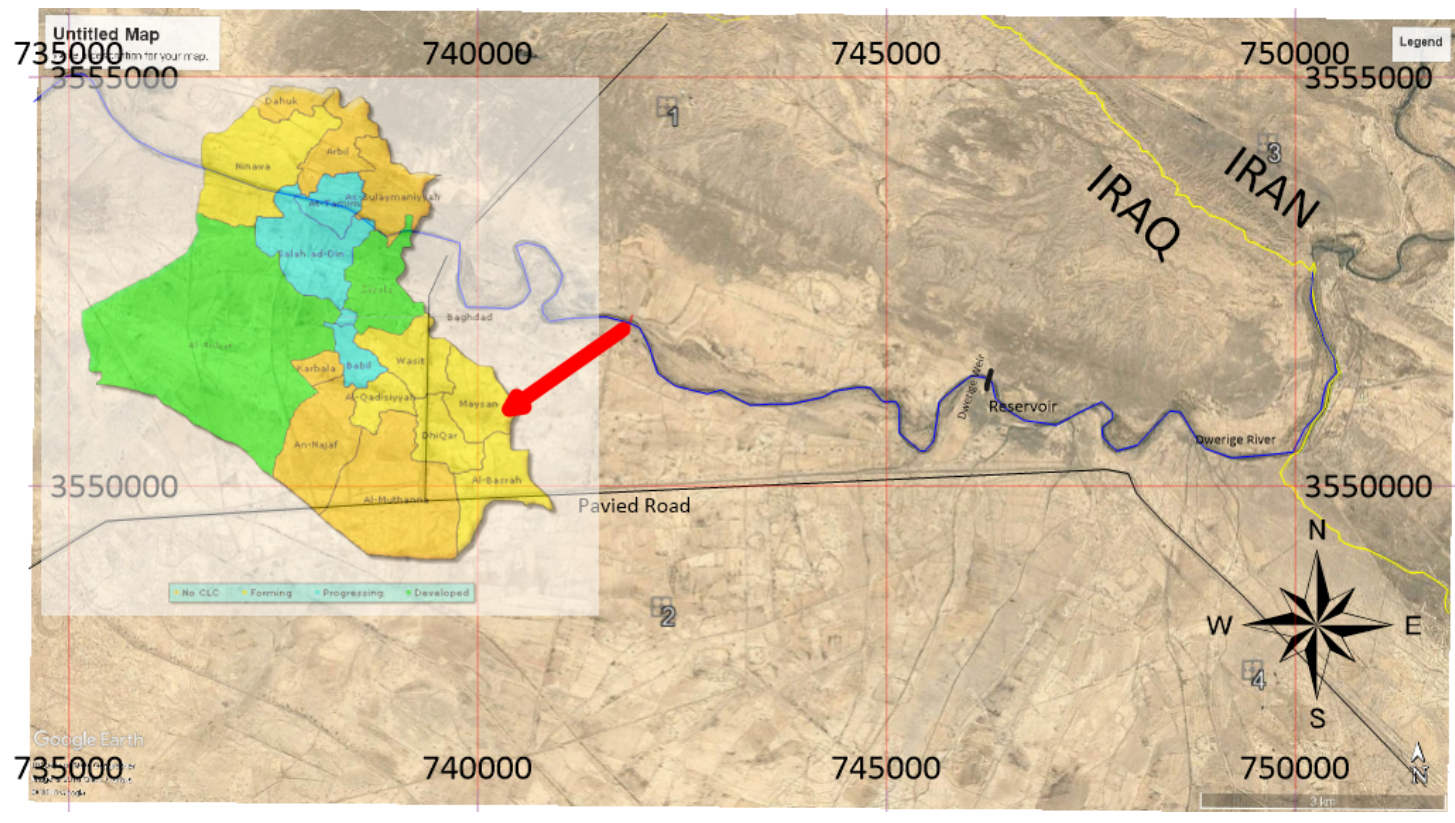

Figure 2. Location of Dweige weir

\subsection{Geotechnical conditions}

\subsubsection{Hydrology}

Dewerige is a common border river between Iraq and Iran, about $90 \%$ of its length laying in Iranian side. The River total length of (202) km, and (800)m weidth. The catchment area (3270) $\mathrm{km}^{2}$. Crossing South East Iraqi borders (about $50 \mathrm{~km}$ to North- East of Maysan). The elevation of river area ais about $35 \mathrm{~m}$ above sea level. and flow in north west direction to hurt in Hor Al-Sinaf [6].

The discharge fluctuated between zero to $994 \mathrm{~m}^{3} / \mathrm{sec}$ according to dry and flooding season respectively (Ministry of Water Resources, Center of Studies and Engineering Designs, 2009). 


\subsubsection{Geology}

Dwerige weir is constructed in alluvial fan area comprised of alluvial and colluvial sediments. These sediments are derived from Zagros mountains to the North East of the area. The oil well records in the area shows that the geology are comprised mainly of Quaternary deposit, especially flood plain sediments ( sandstone, siltstone and claystone ) overlying a Tertiary deposit Mukdadya and Bai Hassan formation. Mukdadya (lower Bakhtiari), lithologically consists of (Gravely sandstone -sandstone - clay stone) with fining upward grained. There are conglomerate beds represent the border between Mukdadya and Bai Hassan, however Bai Hassan formation comprise (conglomerate - claystone - sandy conglomerate). Weir site is covered with recent Alluvial and Aeolian deposits derived from above geological formations, reached to $50 \mathrm{~m}$ depth, with some Quaternary \& Tertiary outcrops [7-9].

\subsubsection{Geotechnical properties}

The site investigation report of the site [10], shows that the area covered with a very dense silty sand SM layer overlying hard to very hard silty clay layer. The depth of the Silty clay CM layer is about $15 \mathrm{~m}$ below ground surface. The hydraulic conductivity of the SM $1 \times 10^{-4} \mathrm{~cm} / \mathrm{sec}$ while the conductivity of the CM layer is about $1 \times 10^{-5} \mathrm{~cm} / \mathrm{sec}$. in this study the CM taken as impervious layer in the model and the model includes only SM layer.

\section{Methodology}

In order to create a numerical model by using SEEP/W, the steady state analysis type is used to simulate hydraulic condition underneath weir foundation [11-13]. The saturated only model is selected to represent material properties because the steady state analysis type in a domain that will remain saturated for the entire duration of the simulation. To solve any model with SEEP/W, the following procedures are followed [14]:

\subsection{Geometry}

The geometrical section of the dam using in SEEP/W as representing in Figure 3. Weir high is $3.5 \mathrm{~m}$ above ground level and the cutoff is $2.5 \mathrm{~m}$ below ground level. Dam base is $6 \mathrm{~m}$. These dimensions were used to construct the model geometry (Figure 4)

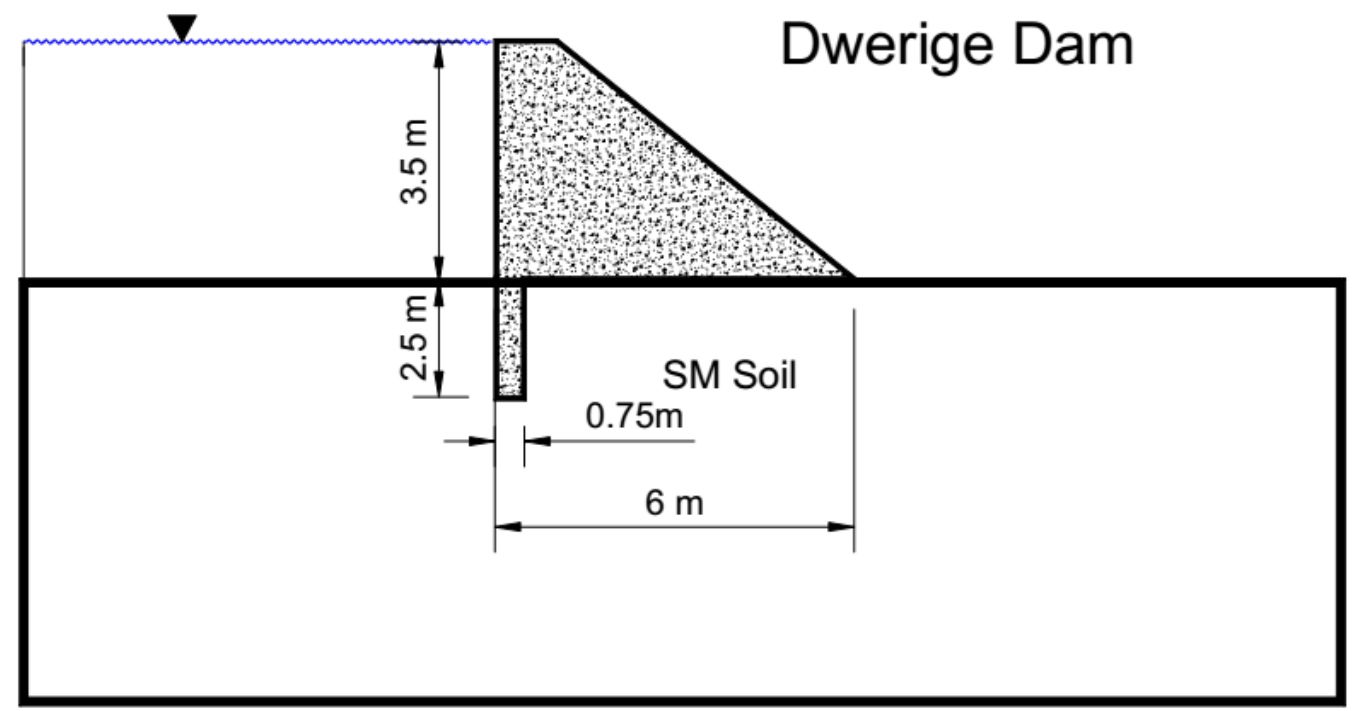

Figure 3: The Dimensions of Dwerige Weir 


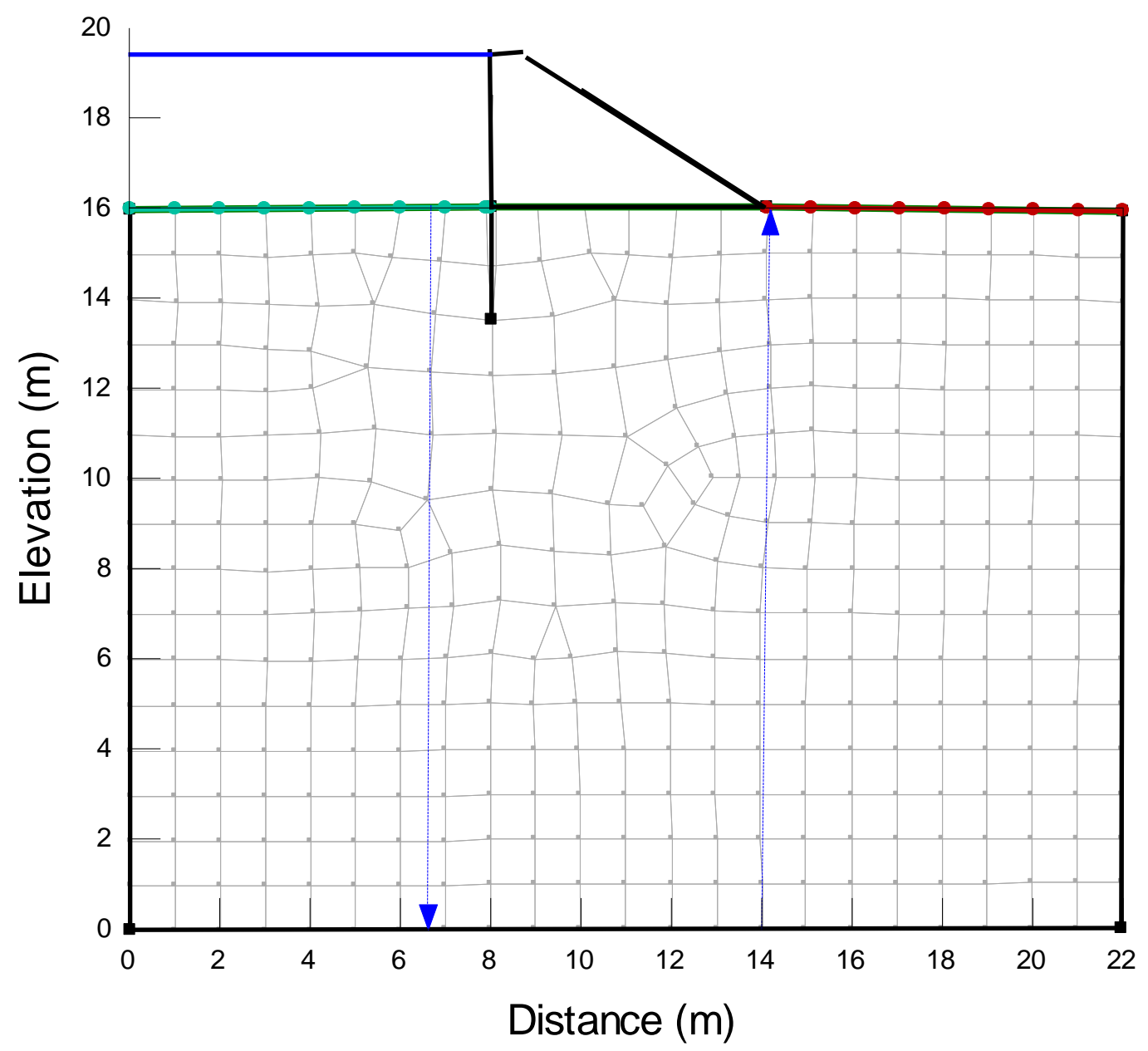

Figure 4. Finite element model constructed by SEEP/W

\subsection{Meshing}

The model section is dividing to a segments (elements) using quad and triangles meshing method. Mesh of 709 Nodes and 654 Elements with approximately global element area size of $1 \mathrm{~m}$ (Figure 4)

\subsection{Material properties}

The saturated hydraulic conductivity, anisotropy, saturated volumetric water content and coefficient of volume compressibility (Mv) are entered for model solving in SEEP/W. Interface material are used for material conductivity equal to zero (Cutoff impermeable wall).

\subsection{Boundary condition}

Head boundary condition are selected because the free water (reservoir) present with model domain.

\section{Results analysis}

Total head, pressure head, pore water pressure and vertical gradient are analysis carefully in this study to get full understanding for soil behavior during weir operation, and to calculate factor of safety.

\section{1-Total head model}

Total head take highly important in potential piping erosion beneath concrete dam foundation. The upstream and downstream head variations of Dwerige weir model were represented in Figure 5. The maximum difference is beneath weir toe in the downstream side. 


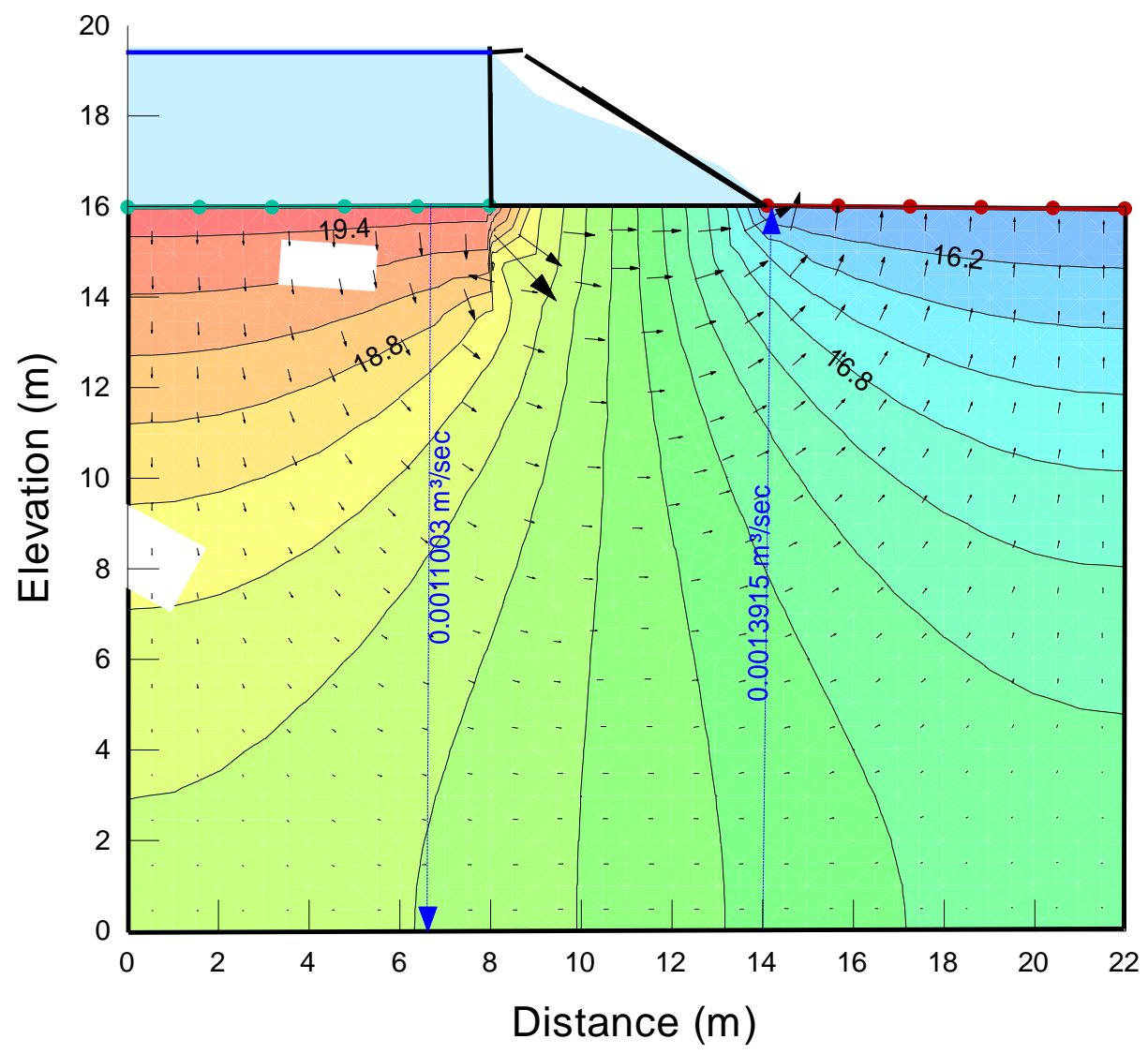

Figure 5. SEEP/W model of the total head in Dwerige dam.

\subsection{Pressure head model}

The pressure head model for the Dwerige dam (Figure 6) shows the difference in of the pressure in the dam toe.

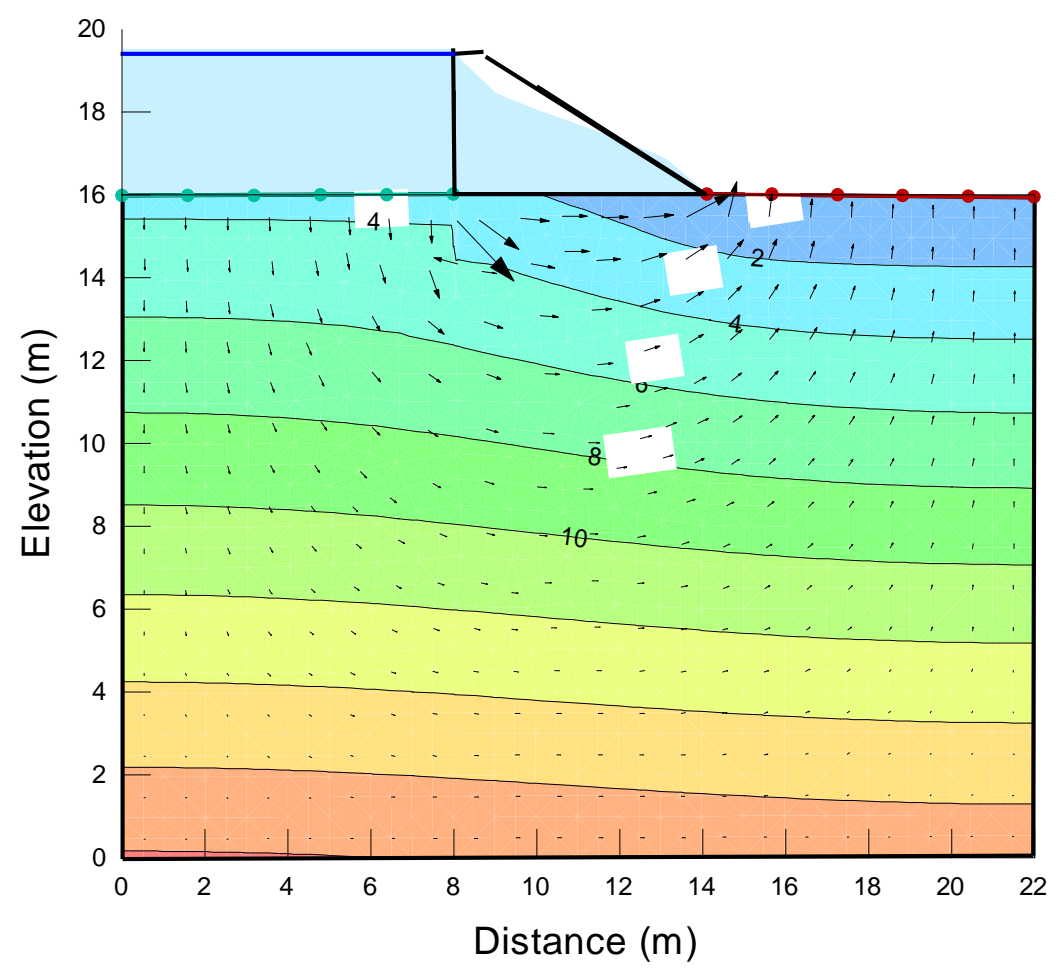




\subsection{Pore water pressure}

Figure 6. Pressure head model

The difference in the total and pressure heads in the dam foundations caused change in the pore water pressure in the soil voids. The pore water pressure model shown in (Figure 7 ).

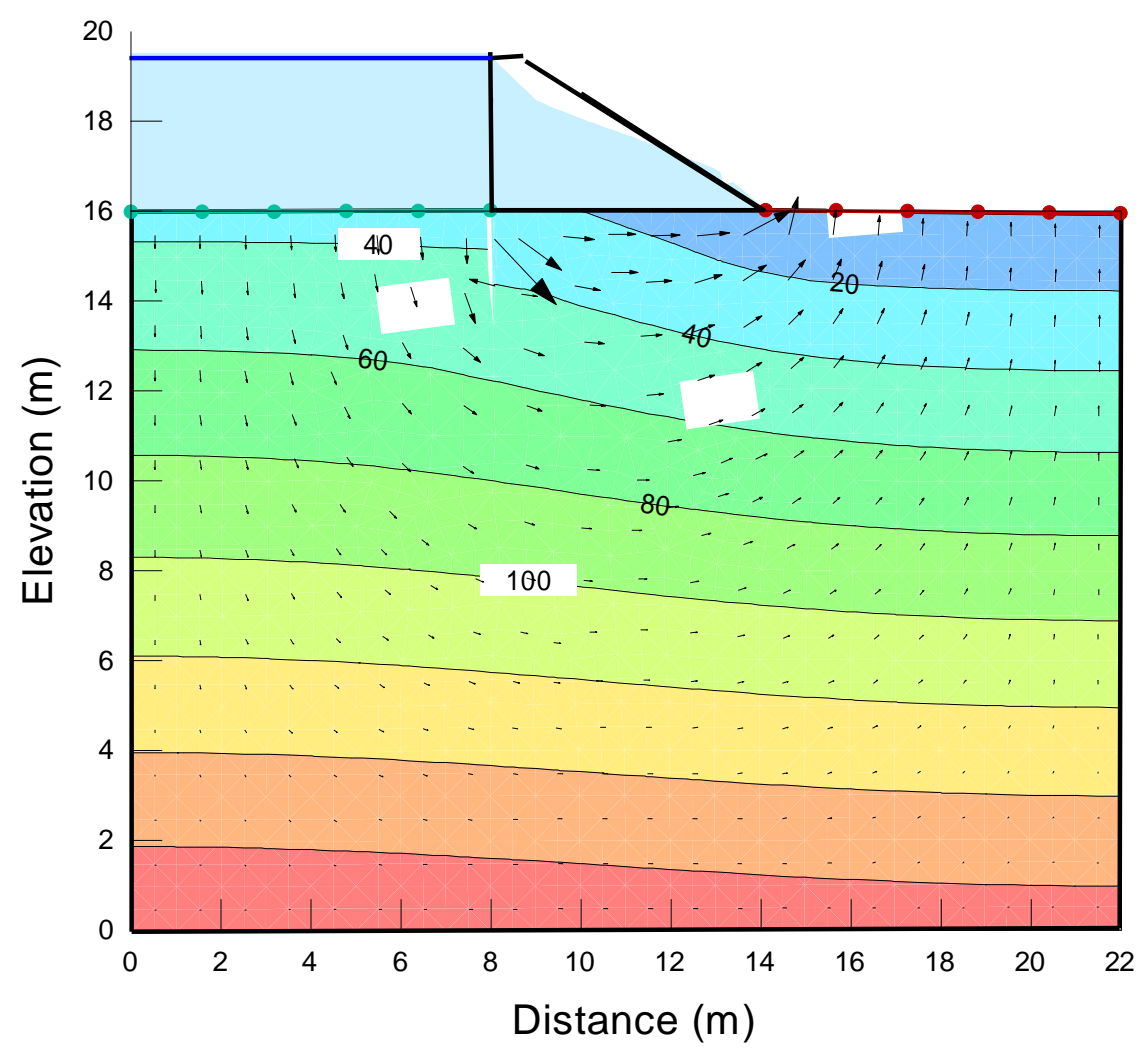

Figure 7. Pore water pressure model $(\mathrm{kN} / \mathrm{m} 2)$ of Dwerige dam section

\subsection{The uplift pressure and vertical gradients below dam}

The vertical gradient and uplift pressure are taken at the ground surface below weir structure. The results are represented in Figures (9 and 10). Other SEEP/W results are represented in Table (1). These results are taken from Figures $(5,6,7)$ above.

Table (1): The SEEP/W model results of Dwerige weir

\begin{tabular}{|c|c|c|}
\hline Item & Upstream & Downstream \\
\hline Total Head $(\mathrm{m})$ & 19.5 & 16 \\
\hline Pressure Head $(\mathrm{m})$ & 4 & 2 \\
\hline Pore Water Pressure $(\mathrm{kN} / \mathrm{m} 2)$ & 40 & 20 \\
\hline Total Seepage $(\mathrm{m} 3 / \mathrm{sec})$ & - & 0.0013915 \\
\hline Vertical Gradient & - & 0.568 \\
\hline
\end{tabular}




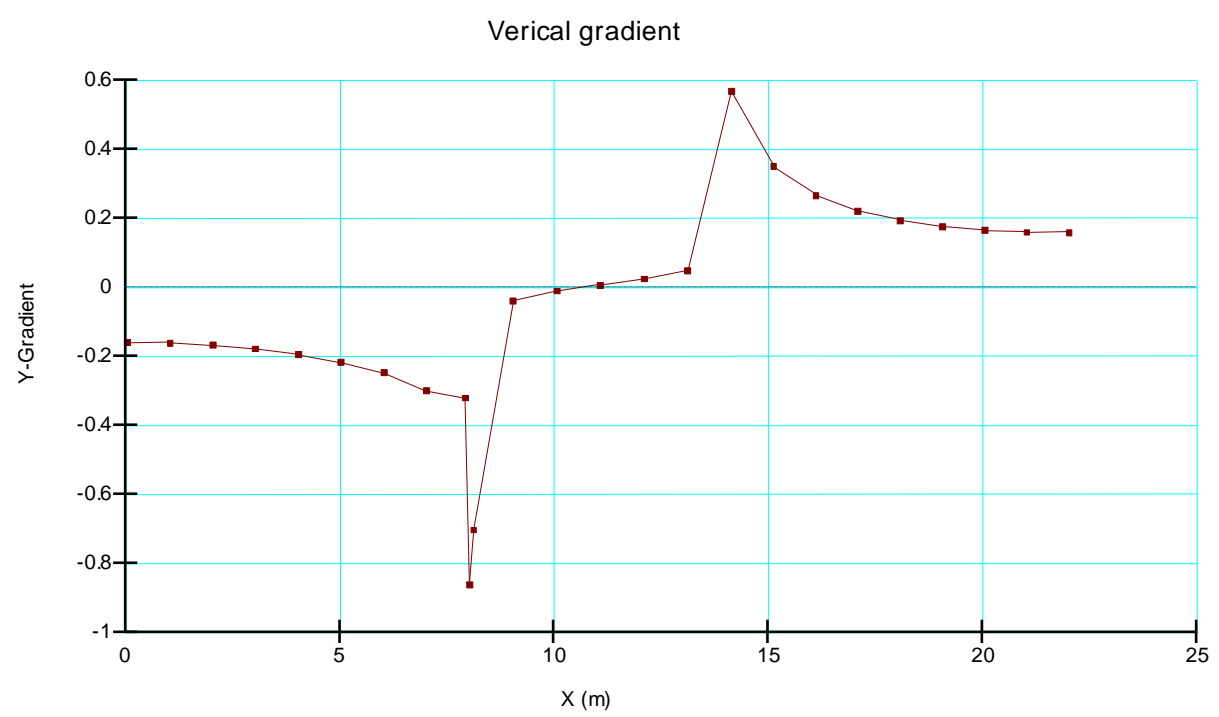

Figure 8. Vertical gradient beneath Dwerige dam foundation

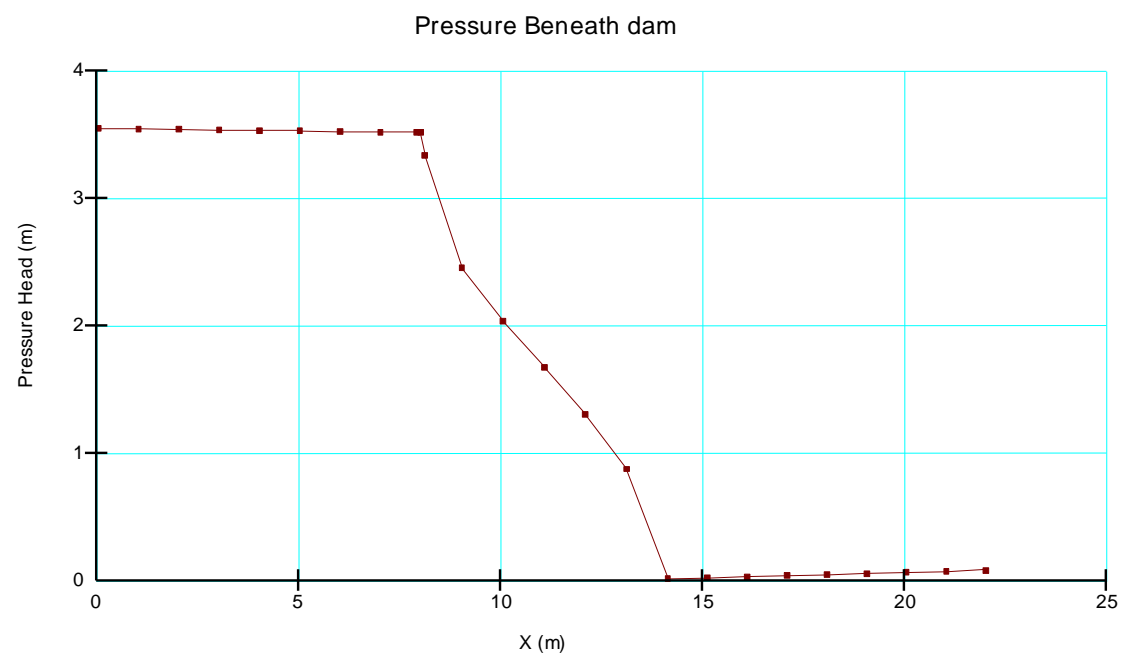

Figure 9. Uplift pressure beneath dam foundation

\subsection{Factor of safety against piping}

The critical area on any dam is the downstream toe where piping erosion, blowout and excessive seepage potentially occurs. SEEP/W has not an automatic way to compute the factor of safety against piping. The seepage gradients at nodes within the finite elements mesh (at the downstream toe). Equation 1 used to compute the factor of safety against vertical seepage exits

$$
\mathrm{FS}_{\text {exit }}=\left({ }_{(\text {sub }} / i_{{ }^{\prime} \mathrm{w}}\right) \ldots . . . \text { (1) }
$$

Where

ssub: Submerged unit weight of weir foundation soil.

$\gamma_{\mathrm{w}}$ : Unit weight of water.

$\mathrm{i}$ is the $\mathrm{Y}$ or vertical hydraulic gradient

The computed factor of safety of the Dwerige weir against piping are 1.9.

\section{4. conclusion}

Dwerige weir built on alluvial high eroded soil of alluvial and colluvial soil. This soil tends to be unstable with seepage and pore water pressure. This type of soil needs carful procedures because soil behavior changes 
widely with water seepage through it [15]. The factors which destroyed some structures in Dwerige area must take in account for any analysis in future. The results of SEEP/W models (Table.1) show us that the factor of safety no enough for the long life stable hydraulic project. The high pore water pressure may cause liquification "blow up" of the soil in the downstream side.

The design features for controlling seepage and erosion beneath the weir includes a slurry trench to the upstream side, weighting berm to the downstream side and grouting zone below weir body.

\section{References}

[1] J. N. Hamza, "Investigation on using magnetic water technology for leaching high saline-sodic soils," Environmental Monitoring and Assessment, vol. 191, no. 8, Jul. 2019.

[2] A. Kulikov, N. Badmaev, D. Sympilova, and A. Gyninova, "The Use of the Value of Heat Cycle to Assess the Energy Stability of Permafrost Soils at the Change of Conditions on the Surface," Geosciences, vol. 9, no. 3, p. 112, Mar. 2019.

[3] H. R. Bdulshaheed, Z. T. Yaseen, and I. I. Al-barazanchi, "New approach for Big Data Analysis using Clustering Algorithms in Information,” Jour Adv Res. Dyn. Control Syst., vol. 2, no. 4, pp. 1194-1197, 2019.

[4] G. Zhu, L. Deng, and Z. Shangguan, "Effects of soil aggregate stability on soil N following land use changes under erodible environment," Agriculture, Ecosystems \& Environment, vol. 262, pp. 18-28, Jul. 2018 .

[5] S. Ni, S. Feng, D. Zhang, J. Wang, and C. Cai, "Sediment transport capacity in erodible beds with reconstituted soils of different textures," CATENA, vol. 183, p. 104197, Dec. 2019.

[6] N. Hamza, "Investigation on using magnetic water technology for leaching high saline-sodic soils," Environmental Monitoring and Assessment, vol. 191, no. 8, Jul. 2019.

[7] V. Kamchoom and A. K. Leung, "Hydro-mechanical reinforcements of live poles to slope stability," Soils and Foundations, vol. 58, no. 6, pp. 1423-1434, Dec. 2018.

[8] J. N. Hamza, "Investigation on using magnetic water technology for leaching high saline-sodic soils," Environmental Monitoring and Assessment, vol. 191, no. 8, Jul. 2019.

[9] K. M. Young and A. Thomson, "Using indirect methods to assess soil health," Crops \& Soils, vol. 52, no. 5, p. 32, 2019.

[10] S. Rashid, A. Ahmed, I. Al Barazanchi, A. Mhana, and H. Rasheed, "Lung cancer classification using data mining and supervised learning algorithms on multi-dimensional data set," Period. Eng. Nat. Sci., vol. 7, no. 2, pp. 438-447, 2019.

[11] D. Weir, D. McQuillan, and R. A. Francis, "Civilian science: the potential of participatory environmental monitoring in areas affected by armed conflicts," Environmental Monitoring and Assessment, vol. 191, no. 10, Sep. 2019.

[12] A. Evangelou and D. Komilis, "Liquid-Phase Respiration Activity Assays to Assess Organic Waste Stability: A Comparison of Two Tests," Sustainability, vol. 10, no. 5, p. 1441, May 2018.

[13] P. Dutta and P. Bhattacharya, "Stability of rectangular tunnel in cohesionless soils," International Journal of Geotechnical Engineering, pp. 1-7, Mar. 2019.

[14] M. Liu, G. Han, and Q. Zhang, "Effects of Soil Aggregate Stability on Soil Organic Carbon and Nitrogen under Land Use Change in an Erodible Region in Southwest China," International Journal of Environmental Research and Public Health, vol. 16, no. 20, p. 3809, Oct. 2019.

[15] X. L. Yang and C. Yao, "Stability of Tunnel Roof in Nonhomogeneous Soils," International Journal of Geomechanics, vol. 18, no. 3, p. 06018002, Mar. 2018. 